\title{
THE REGIONAL APPROACH TO THE HOUSING PROBLEM
}

\author{
Earle S. Draper* and Tracy B. Augur**
}

The "housing problem" is so generally associated with life in cities that it is difficult to think of it in any other terms. Basically it is not a problem of life in cities, but of life wherever it is lived. It is the problem of securing shelter of a type that meets the needs and the means of those that seek it. It is associated with the means of living far more closely than with the place of living. For that reason any attempt to localize it-to say that it is a New York problem or a Chicago problem or an Atlanta problem, a city problem or a rural problem-is missing its real challenge. The problem is to bring together satisfactory facilities for shelter and the means of livelihood that will support them. It does not particularly matter where they are brought together, so long as they exist at the same time and in a convenient and usable relationship.

Mankind is constantly seeking new means of livelihood as old ones fail, or cease to satisfy. It was that urge that carried settlement across the continent and that started the great drift from farm to city. The housing problem goes always with the population, westward or cityward, or in any new direction that people take in search of a living. What new direction that search must take to give fresh opportunity to those now without means of self support, is a question on whose answer hangs the real solution of the housing problem.

There is a scrious housing shortage in the United States today due to the curtailment of construction during recent years, but it has been concealed by the doubling up of families and the continuance in use of thousands of unfit dwellings that should have been scrapped long ago. It is rendered doubly serious by the fact that much of the existing housing now in use, both good and bad, is in the wrong place. To the social dangers arising from overcrowding and the occupancy of unfit habitations is added the economic danger of having millions of citizens housed where there is

\footnotetext{
- B.S., I915, Massachusetts State College, Amherst, Mass. Studied and traveled in Europe, 1922. Director of Land Planning and Housing, Tennessee Valley Authority. Pionecr landscape architect in southern states. Author: Southern Textile Village Planning, Landscape Design in the South. Contributor to numerous periodicals.

* B.A., I9r7, Cornell; M.L. Arch., I921, Harvard. Chief, Regional Planning Section, Tennessec Valley Authority. In general city planning practice since I921. Consultant to Detroit City Plan Commission, summer of 1933 , in connection with slum clearance project. Consultant to the Housing Division, Public Works Administration, till joining staff of Tennessee Valley Authority.
} 
no hope of future employment that will give them decent living. Temporary hardship and discomforts can easily be borne if the future holds some promise, but a hopeless future will break the hardiest spirit-and wreck the strongest nation. Therefore the present emergence of housing in the public consciousness becomes significant, not because of the re-discovery of slums or the admission that their clearing is a public responsibility, but because of the official interest of the Administration in what lies back of slums, and in the economic order that has produced them. The growing willingness to attack the whole problem of modern living, and not just the housing phase of it, is the hopeful sign. It is only by such a broad attack that housing may be dealt with successfully.

It is obvious that such an attack can be made on nothing less than a regional basis. The improvement of housing conditions does not consist in the mere rebuilding of houses or neighborhoods that now are obsolete, but in their replacement by new building operations, which may more properly be undertaken fifty or a hundred or a thousand miles away from the old site than upon it. A city's housing difficulties arise more often from the necessity of housing more people than its opportunities for livelihood can decently support, than from a demand for shelter that really overtaxes the supply. So the solution of the difficulty is more apt to be found in the removal of the surplus population to points where they can afford a decent living than it is in building more and better houses for the people where they are.

In seeking a sound regional approach to the housing problem, we may profitably re-examine the simple proposals of Sir Ebenezer Howard, who with a similar approach, looked beyond the English slums thirty-six years ago to the things that had produced them, and who proposed a remedy that fits the situation that we face today as well as it did the English situation then. England at the close of the last century had become predominantly urban, after long being predominantly rural, for the simple reason that machinery had released manpower from the farms and furnished employment in manufacturing instead. It was no longer necessary for so large a part of the population to work in agriculture, and agriculture no longer offered the opportunities of other forms of industry. The factories, for reasons more important then than now, found urban locations advantageous, and the cities became the seats of opportunity, drawing population from the rural areas and building up congestion and overcrowded housing. The means of livelihood was the controlling factor in the situation, and where it was, the need for housing followed. It made no difference that healthful and commodious homes in the country stood deserted, or that spacious building land lay idle all about the manufacturing centers, just out of reach. The people lived where their work was; they had no other choice.

Howard realized the futility of trying to turn the movement back toward the farms when there was no economic need for a large farming population. He also realized the futility of trying to re-make the great cities into something really fit to live in, for they had already gone too far in the other direction. So he proposed to 
direct the population movement, not back to the farms nor into the obsolescent cities, but into a new type of community that he called a Garden City.

These communities were to absorb the population released from agriculture instead of allowing it to be engulfed in the spreading bulk of the overcrowded centers. But they themselves were to be prevented from becoming overcrowded by limitations on the density of settlement and on the ultimate size to which each town might grow. In order to remove the usual tendency to ignore and over-ride such limitations, the actual land ownership and construction of each city was to be placed in the hands of a limited-profit corporation which would build in the interest of the future inhabitants instead of for their exploitation. Each town would be expertly planned from the outset, located on a carefully selected site, and built according to the best and most modern practices, which included, in Howard's scheme, a protective belt of open land around each city. Each town would have, because of its close association with the surrounding country and the open character of its development, all the advantages of rural living. But in addition it would contain the industrial and business opportunities of the city, and the social benefits to be derived from life in an urban community.

What Howard proposed was a solution of the housing problem, not by building model tenements or workers' suburbs, but by taking the population before it reached the slums and giving it housing facilities of a far superior sort in close association with the means of livelihood that would support them. Instead of a London steadily becoming, as Patrick Geddes has since described it, "more and more of worse and worse"- of a London constantly spreading and getting more congested, and providing poorer and poorer living for its people-Howard pictured a greater London made up of a central city with satellite communities added about its borders to accommodate its growth. Each satellite, each garden city, would be separated from the others by belts of open land for farming or forests or recreation, and each would be a complete social and economic unit within itself, yet all would be connected by road and rail, and help to support in the central city those larger enterprises of commerce or industry or culture for which the individual satellites might be too small.

The picture therefore was not.merely of a new type of city, but of a new type of region, of a new population pattern and a new relationship between the people and the land they occupied. Instead of wide deserted rural areas on the one hand, and great hopeless blots of population on the other, there would be a dotting of small industrial communities in the midst of rural land, bringing into close and harmonious relationship the pursuits of agriculture and manufacturing and commerce and, most important of all, healthful, contented living. The garden cities would bring to rural areas new markets for their crops, new opportunities for part time employment, and new centers of social and cultural activity, and so in addition to providing a new type of environment for city life would improve the rural environment as well. 
Such, sketched very briefly, was the Garden City Idea; but it did not remain just an idea. London and Liverpool and Glasgow went on growing in the same old way, and no revolution took place in the mechanics of city building; but the idea did take root, and so strongly that within a few years an Association had been built up about it with capital enough to acquire a site and begin the construction of the first Garden City of Letchworth, thirty-five miles from London. Unlike many ventures founded in a burst of zeal over some social or religious dogma, the new Garden City grew and prospered, until today it is a well established city, providing for some fifteen or sixteen thousand people exactly what Howard hoped it would provide-an opportunity for happy, healthy living coupled with diversified employment. On the strength of its success a second Garden City, Welwyn, was started eighteen years later, not far from Letchworth, and it too has established itself firmly among the communities of England.

Now in the United States we are facing a tremendous housing problem-but it is not alone a problem of houses. It is a problem, of finding for millions of people a form of livelihood that will afford them shelter, as well as food and clothing and the amenities of life. It will avail us nothing to build new houses where there is no prospect of employment to support them. Nor will it do any permanent good to enter the big employment centers and rebuild where the multiple mistakes of a metropolis make good housing unattainable.

We are facing the situation that Howard found in England, but in a later stage. We are not witnessing the drift of population from farms to cities, but the results of it, results that have produced abominable housing in every city of the land and in addition have so upset the economic balance that the future seems to hold little hope of more than partial and insufficient livelihood for many of those who flocked cityward during the past several decades. Obviously this is not a problem to be solved city by city or slum by slum. It is part of the national economy, and as such must be tackled on a national scale. Because sound solutions will ignore city limits and metropolitan areas and state lines, and deal with people and their relation to the land and its resources, the problem is distinctly regional in character.

Several angles of the New Deal program indicate that the housing problem is being approached from this regional standpoint by the Administration. The Subsistence Homestead movement and the recently announced policies of the Relief Administration are distinctly along this line, and the great Tennessee Valley experiment in regionalism, although not specifically linked to housing, inevitably embraces it within its scope.

Whatever the popular conception of "subsistence homesteading" may be, it is obvious from the actions and statements of those directing this Federal enterprise that a bare means of existence for the homesteaders is not the goal, but rather a means of supporting a full, well-rounded life. Persons stranded by the closing of mines or mills that formerly employed them, families unable to make a living in big 
cities, farmers on lands that will no longer yield them livelihood, are being colonized in new communities that offer decent shelter, a chance to produce food for the family needs, and enough employment in industry or commercial agriculture to support a simple but comfortable life for all. The colonies created out of the Subsistence Homestead fund are frankly experimental and set up as demonstrations, but similar measures appear to be contemplated on a larger scale under the program of the Relief Administration for the coming year, announced at the end of February.

The Tennessee Valley Program is different in conception although its objectives are broadly similar. Instead of being a country-wide attack upon a few specific problems, it is an attack within a specific region on all the problems of an integrated social and economic structure. It deals with the whole of life and with housing as an essential part of it. It aims at the gradual achievement of a planned regional economy, rather than the emergency solution of certain pressing problems of the moment.

The Tennessee Valley is the largest and most distinct region that has as yet been given official recognition in this country. It extends into seven states, covering the watershed of a great river and all its tributaries, and embraces a wide diversity of resources;-agriculture of all sorts, from the cotton fields of Alabama to the high plateau farms of the Cumberland and Blue Ridge Mountains; timber resources; rich deposits of coal, iron, copper, zinc, bauxite, feldspars, marble, slate, limestone, phosphate rock, and other minerals; and great developed and potential sources of water power. It has a greater wealth and diversity of basic resources than any other region in the country, and could not offer a firmer basis for the building of a sound economic structure.

The Valley also embraces all types and conditions of housing, both good and bad. The best and the worst in other sections have their counterparts in this great area. There are slums in its cities, and dilapidated, insanitary houses on its farms, to the same degree that such conditions are found everywhere. The Valley is not lacking in the need for better housing, nor in the unemployment and poverty which there as elsewhere have kept bad housing on the market. It is ideally suited for a demonstration of a housing method that couples good houses with means for gainful occupation through which people may afford them.

The Tennessee Valley Authority, created by Act of Congress in May 1933, is not set up as a housing agency, nor is it engaged upon a housing program. But it is charged, among other things, with making surveys and plans "for the general purpose of fostering an orderly and proper physical, economic and social development of the Valley," and may be authorized by the President "to make such studies, experiments or demonstrations as may be necessary and suitable to that end." In its first major construction operation-the building of the Norris Dam-an opportunity arose to make a housing demonstration that would fill a definite place in the development of the Valley program. As a result there is now rising near the dam the new 
town of Norris, a town in which good housing will be coupled with industrial, commercial and agricultural employment to furnish wholesome living to several hundred families.

The building of the Norris Dam called for the housing of a large part of the labor and supervisory force near the site, for the two years or more that the work would consume. Rather than spend large sums on temporary dormitories, houses, shops, sewer and water systems and the other facilities of a large construction camp that would have no lasting value, the Authority early decided to build in a form that would contribute to the permanent well-being of the area. The town of Norris will therefore serve a dual purpose, at the outset housing personnel connected with the building of the dam and associated operations, but gradually introducing during the construction period enough industries and other employment opportunities to help absorb labor released when the dam is finished. The first unit of the town, now nearing completion, will house some two hundred families, but the utilities and basic town plan are designed for expansion to a population of four or five thousand people. The repair shops for the construction work are located to serve as the nucleus for an industrial section; the poultry, dairy and truck farms needed to supplement the local food supplies for the large construction force will remain as part of the town's agriculture; the new highway that brings supplies to the construction job will form a scenic and utilitarian link from Norris to the railroads on the west and to Knoxville, twenty miles to the southeast. In short every feature of the construction operations that could be given permanent utility by being incorporated in a permanent town was so designed. And as a protection to the new community from the shack colonies and speculative sub-divisions which ordinarily arrive to exploit the labor on the job and the gullible back home, a wide protective belt has been acquired completely surrounding the town area with farm and wooded land that will be kept open in perpetuity. The entire site of about three thousand acres is being developed as a single entity, and under one central control.

When the Norris Dam is finished, bringing enlarged resources of cheap power to help develop the natural resources of the Valley, the town of Norris will be ready to demonstrate the advantages of combining new industries with new housing in new communities planned for modern living. It will demonstrate what the Garden Cities of England have demonstrated, that the diversified employment opportunities and social advantages of urban life can be enjoyed in a rural setting, and that the small town, properly planned internally as well as in its relation to the country about it, can offer most, if not all, of the benefits that come from life in big cities-without its disadvantages. It will be greatly helped in this demonstration by one of the points it holds in common with the Garden City, namely that the land on which it is built has been bought at acreage prices and will be held in trust for the community -which is another way of saying that the town is being built to provide a new and finer type of urban environment for the American people and not to furnish speculative profits for land exploiters. 
The town of Norris is the outgrowth of a construction operation. It is not an indication of a housing policy, nor is it essentially a model community. But it is strong evidence of a desire on the part of the Tennessee Valley Authority to attack each of its many problems with the single broad goal for which it was created; the evolution of a way of living in the Valley that will assure to every citizen a decent habitation, wholesome surroundings and an opportunity to enjoy them through the fruits of his own labor.

Other problems lie ahead, holding similar opportunities to deal with housing as part of the regional life, and to demonstrate in various ways the methods by which people may be enabled to secure and keep good homes. The building of the Norris Dam will form a reservoir flooding some seventeen hundred farm and village houses. Several hundred more will be rendered inaccessible, or their supporting farms will be cut of by the reservoir, so that around two thousand families will be forced to move by this single operation. A major housing problem is presented there; again not merely a matter of housing, but of the re-establishment of life for people forced to give up their homes, their accustomed mode of living, and all their old associations.

Some of the displaced families will make their own adjustments, and buy new farms or homes with the money paid them for those they now possess. But readjustment is not simply a matter of settling on new farms. Farming alone does not offer any guarantee of a reasonable living. Many of those who will be displaced are now making little more than a bare existence. If they are to be enabled to enjoy the fuller life that the proper development of the Valley is expected to bring them, they will have to be furnished gainful employment in addition to their farming, or helped in the selection of the best among the available farm lands, and in their operation in a profitable way.

This presents an opportunity for constructive planning, and for the intelligent re-housing of hundreds of families in such relation to their surroundings that they will be enabled to afford good homes. It is a problem that calls for a regional solution, and a knowledge of all the factors of regional development, lest re-settlement take place in the path of some future reservoir that is part of the Authority's program, or in a locality whose access to markets will be cut off by changes in the highway system, or on lands that are sub-marginal in character.

Other parts of the Valley program will seek to introduce into rural communities new gainful occupations to help stop the drift of the younger generations away in search of jobs, and to bring to these communities, through the magic of cheap electricity, the modern conveniences and the opportunity for local industries that now are lacking.

These items in the work of the Tennessee Valley Authority are not cited as a complete program, but as instances of the regional approach, which alone is broad enough to meet the housing problem of today; the problem of helping people to 
find an adequate living and a fit living place where both may be enjoyed. The full program of the Authority is still in the making. It claims no discoveries or magic formulas to solve a problem that has been with us since the world began. But it does recognize that the housing problem has constantly become more involved with the progress of modern civilization, and that it is increasingly beyond the power of individuals to cope with for themselves. And so good housing, instead of being discussed in terms of better bathrooms or less congested tenements, is given its proper place in the regional economy, to be achieved as part and parcel of that "more abundant life" which our national resources are fully able to provide if properly directed for the public good. 